\begin{tabular}{c} 
International Journal of Scientific World, $4(1)(2016) 19-22$ \\
International Journal of Scientific World \\
SPC \\
Website: $\begin{array}{c}\text { www. sciencepubco.com/index.php/IJSW } \\
\text { doi: } 10.14419 / \text { ijsw.v4il.6064 } \\
\text { Research paper }\end{array}$ \\
\hline
\end{tabular}

\title{
Phytochemical analysis, mineral composition and in vitro antioxidant activities of Celosia argentea leaves
}

\author{
Usunobun Usunomena*, Ekpemupolo I. Samuel \\ Department of Basic sciences (Biochemistry unit), Faculty of Basic and Applied sciences, Benson Idahosa University, \\ P.M.B 1100, Benin City, Edo State, Nigeria \\ *Corresponding author E-mail:uusunobun@biu.edu.ng
}

\begin{abstract}
Background: Celosia argentea, a traditional vegetable in West and Central Africa is widely grown for ornamental purpose in the tropics and subtropics such as in Malaysia. The aim of this study is to determine phytochemicals, mineral composition and in vitro antioxidant activities of Celosia argentea leaves.

Methods: Qualitative phytochemical screening was carried out using standard procedures, Mineral analysis was carried out using Atomic Absorption Spectrophotometer (AAS) while antioxidant potential, free radical scavenging and reducing power scavenging activity were also carried out.

Results: The phytochemical composition revealed the presence of active ingredients such as glycosides, steroids, Saponins, Phenols, Flavonoids, and alkaloids while mineral analysis showed higher concentration in calcium $(295 \mathrm{mg} / 100 \mathrm{~g})$ and least concentration in chromium $(0.85 \mathrm{mg} / 100 \mathrm{~g})$. Other minerals and their concentrations includes magnesium $(122.53 \mathrm{mg} / 100 \mathrm{~g})$, potassium $(128.33 \mathrm{mg} / 100 \mathrm{~g})$, sodium $(71.32 \mathrm{mg} / 100 \mathrm{~g})$, iron $(35.16 \mathrm{mg} / 100 \mathrm{~g})$, zinc $(5.42 \mathrm{mg} / 100 \mathrm{~g})$, copper $(2.18 \mathrm{mg} / 100 \mathrm{~g})$, manganese $(1.86 \mathrm{mg} / 100 \mathrm{~g})$. Moreover, DPPH (2, 2-diphenyl-1-picrylhydrazyl) scavenging activity and reducing power activity of Celosia argentea increased as the concentration increases.

Conclusion: The present study reveals therapeutic potential of Celosia argentea leaves due to its bioactive compounds and minerals. Also, Celosia argentea possess powerful antioxidant activity and can therefore offer good protection against oxidative damage.
\end{abstract}

Keywords: Celosia argentea; DPPH; Minerals; Phytochemicals; Reducing Power.

\section{Introduction}

Celosia argentea is an annual herbaceous vegetable of the family Amaranthaceae known as sokoyokoto among the Yorubas insouth-western Nigeria. The leaves and stems are cooked into soups, sauces or stew with other ingredients [1]. In India, the leaves mixed with honey are applied to inflated areas and the seeds are used for the treatment of diabetes mellitus [2]. In southeast Asia, the flowers are used as medicine for dysentery, haemoptysis and menstruation problems [1].In Ethiopia and Democratic Republic of Congo the seeds are used as medicine for the treatment of diarrhea, dysentery and muscle troubles [3-4]. In Kenya, the Masai use its liquid extract as a bodywash for convalescents [5]. Externally, Celosia argentea functions as a disinfectant as well as treat inflammation [6], dysuria, poultices for broken bones [7], ailment for eyes and liver [8], mouth sore, blood diseases, and others [9]. The aim of this work is to determine the phytochemicals, mineral composition and in vitro antioxidant activities of Celosia argentea leaves.

\section{Materials and methods}

2.1. Collection, identification and preparation of plant materials
Fresh leaves of Celosia argentea were collected from a local farm in south eastern part of Nigeria. Identification and authentication were carried out after which the leaves were washed and air dried at room temperature for three (3) weeks. The dried leaves were grounded into fine powder using an electric blender and stored in a cool dry container until use for analysis.

\subsection{Phytochemical analysis}

Qualitative phytochemical screening to determine the presence of alkaloids, tannins, saponins phenols, anthraquinones, flavonoid and glycosides using standard methods as described by [10-14] were carried out.

\subsection{Mineral analysis}

Mineral analysis was carried out using Atomic Absorption Spectrophotometer (AAS) as previously done by Usunobun and Okolie, [15-16].

\subsection{Determination of reducing power ability}

The reducing power activity of Celosia argentea leaves was carried out using the reducing power method. A mixture containing $2.5 \mathrm{ml}$ of $0.2 \mathrm{M}$ phosphate buffer $(\mathrm{pH} 6.6)$ and $2.5 \mathrm{ml}$ of $\mathrm{K}_{3} \mathrm{Fe}(\mathrm{CN})_{6}(1 \% \mathrm{w} / \mathrm{v})$ was added to $1.0 \mathrm{ml}$ of stock Celosia argentea leaves filtrate $(0.2-1.0 \mathrm{mg} / \mathrm{ml})$ prepared in distilled water. 
The resulting mixture was incubated for $20 \mathrm{~min}$ at $50^{\circ} \mathrm{C}$, followed by the addition of $2.5 \mathrm{ml}$ of TCA $(10 \% \mathrm{w} / \mathrm{v})$, followed by centrifugation at $3000 \mathrm{rpm}$ for $10 \mathrm{~min} .2 .5 \mathrm{ml}$ of the supernatant was mixed with $2.5 \mathrm{ml}$ of distilled water and $0.5 \mathrm{ml}$ of $\mathrm{FeCl}_{3}(0.1 \%$ $\mathrm{w} / \mathrm{v})$. The absorbance was measured at $700 \mathrm{~nm}$ against reagent blank sample. Increased absorbance of the reaction mixture indicates higher reducing power of Celosia argentea leaves.

\section{5. diphenyl-1-picrylhydrazyl (DPPH) radical scaveng- ing ability}

The DPPH method was used for the determination of DPPH free radical scavenging activity of Celosia argentea leaves as follows: DPPH $(1 \mathrm{ml}, 0.135 \mathrm{mM})$ prepared in methanol was mixed with $1.0 \mathrm{ml}$ of stock Celosia argentea leaves filtrate ranging in concentration from 0.2 to $1.0 \mathrm{mg} / \mathrm{ml}$. The reaction mixture was then vortexed thoroughly and left in the dark at room temperature for 30 min. The absorbance was measured at $517 \mathrm{~nm}$. The scavenging ability was calculated using the equation: $\mathrm{DPPH}$ scavenging activity $(\%)=\left[\left(\mathrm{Abs}_{\text {control }}-\mathrm{Ab}-\right.\right.$
$\left.\left.\left.\mathrm{s}_{\mathrm{sample}}\right)\right] /\left(\mathrm{Abs}_{\mathrm{control}}\right)\right] \times 100$,

Where: $\mathrm{Abs}_{\text {control }}$ is the absorbance of DPPH + methanol and Ab$\mathrm{s}_{\text {sample }}$ is the absorbance of DPPH radical + sample (sample or standard).

\subsection{Statistical analysis}

Data obtained from this study were expressed as mean value \pm standard deviation.

\section{Results}

Phytochemical screening reveals Celosia argentea leaves to contain flavonoids, saponins, alkaloids, phenols etc as shown in table 1

Table 1:Phytochemical Screening of Celosia argentea Leaves

\begin{tabular}{ll}
\hline Phytochemicals & Celosia argentea \\
\hline Flavonoids & Positive \\
Saponins & Positive \\
Alkaloids & Positive \\
Tannins & Negative \\
Phenols & Positive \\
Glycosides & Positive \\
Anthraquinones & Negative \\
\hline
\end{tabular}

The result of the minerals as shown in table 2 shows Celosia argentea to be higher in calcium $(295 \mathrm{mg} / 100 \mathrm{~g})$ and least in chromium $(0.85 \mathrm{mg} / 100 \mathrm{~g})$. Other minerals includes magnesium $(122.53 \mathrm{mg} / 100 \mathrm{~g}), \quad$ potassium $\quad(128.33 \mathrm{mg} / 100 \mathrm{~g})$, sodium $(71.32 \mathrm{mg} / 100 \mathrm{~g})$, iron $(35.16 \mathrm{mg} / 100 \mathrm{~g})$, zinc $(5.42 \mathrm{mg} / 100 \mathrm{~g})$, copper $(2.18 \mathrm{mg} / 100 \mathrm{~g})$, manganese $(1.86 \mathrm{mg} / 100 \mathrm{~g})$

Table 2:Mineral Composition of Celosia argentea Leaves (mg/100g)

\begin{tabular}{ll}
\hline Mineral & Celosia argentea $(\mathrm{mg} / 100 \mathrm{~g})$ \\
\hline Calcium & $295.00 \pm 3.65$ \\
Magnesium & $122.50 \pm 4.01$ \\
Potassium & $128.33 \pm 5.08$ \\
Sodium & $71.32 \pm 2.76$ \\
Phosphate & $135.79 \pm 5.58$ \\
Iron & $35.16 \pm 3.05$ \\
Zinc & $5.42 \pm 0.90$ \\
Copper & $2.18 \pm 0.76$ \\
Manganese & $1.86 \pm 0.21$ \\
Chromium & $0.85 \pm 0.05$ \\
\hline Values are means \pm SD for 2 determinations
\end{tabular}

The scavenging activity of DPPH radical exerted by the leaf is summarized in Fig.1. The scavenging effect of Celosia argentea leaves in the range of $0.2-1.0 \mathrm{mg} / \mathrm{ml}$ increased in a concentration- dependent manner. Fig.2 showed that the reducing power of Celosia argentea leaves also had a dose-dependent effect i.e increased with increasing concentrations.

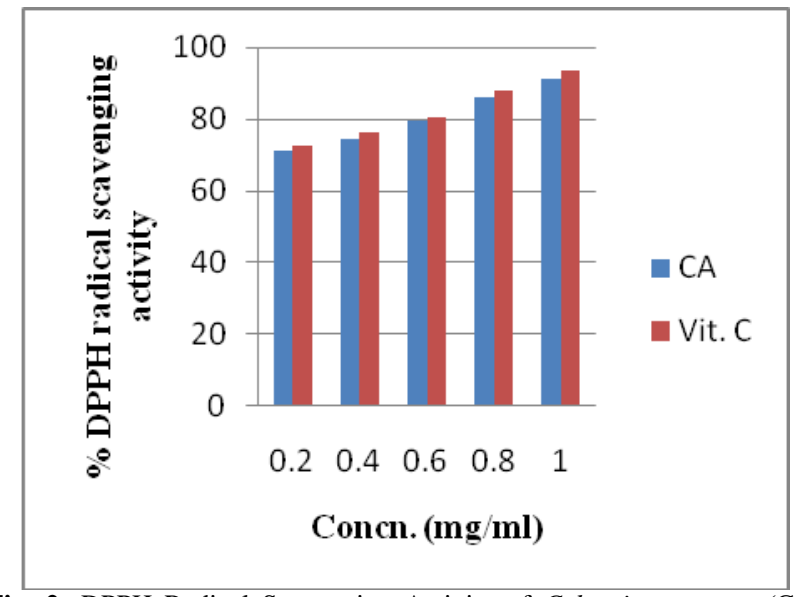

Fig. 2: DPPH Radical Scavenging Activity of Celosaia argentea (CA) Leaves.

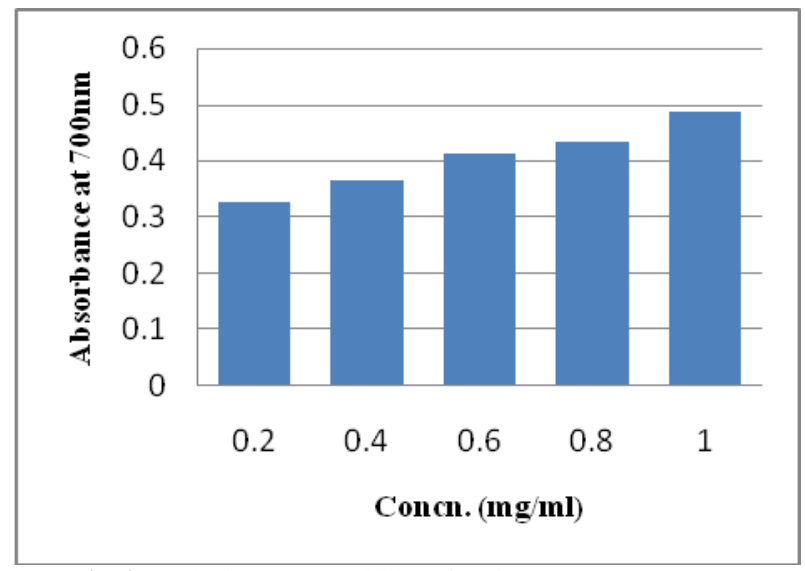

Fig. 2: Reducing Power Ability of Celosia argentea Leaves.

\section{Discussion}

This study showed that Celosia argentea leaves contained flavonoids, phenolics, saponins, glycosides, steroids and alkaloids. Flavonoids have been reported to exert wide range of biological activities. Including anti-inflammatory, antibacterial, antiviral, antiallergic, cytotoxic antitumour, treatment of neurodegenerative diseases and vasodilatory action [17]. Flavonoids are known to inhibit lipid-peroxidation, platelet aggregation, capillary permeability and fragility, cyclooxygenase and lipoxygenase enzyme activities. They exert these effects as antioxidants, free radical scavengers and chelators of divalent cation [18]. Flavonoids possess antidiarrhoeal [19] antibacterial [20] and antimicrobial [21] properties. This may be the scientific basis for the use of Celosia argentea for the treatment of skin diseases, pile, dysentery, inflammation, haematological and gynaecologic disorders Saponins have been reported to have antihyper-cholesterol, antiinflamatory, cardiac depressant properties [11] and appear to kill or inhibit cancer cells without killing the normal cells in the process [22]. Saponins have also been reported as antimicrobial and antifungal [23], thereby suggesting Celosia argentea potentials in treatment of fungi diseases like ring worm, guinea worm, skin diseases, craw-craw. In addition to antimicrobial and antifungal activities, saponins also aids digestion and enhances nutrient absorption [23].

Green leafy vegetables provide humans with adequate amounts of many vitamins and minerals and thus occupy an important place among the food crops. They are valuable in maintaining alkaline reserve of the body because of their nutrient and mineral contents 
[24]. Celosia argentea in this study shows richness in calcium, potassium, sodium, magnesium, iron, zinc etc.

Sodium content of Celosia argentea $(71.32 \mathrm{mg} / 100 \mathrm{mg})$ compared favourably with $69.49 \mathrm{mg} / 100 \mathrm{~g}$ of Annona muricata but high when compared to $48.31 \mathrm{mg} / 100 \mathrm{~g}$ of Vernonia amygdalina as reported by Usunobun and Okolie [15-16]. Potassium content of Celosia argentea $(128.33 \mathrm{mg} / 100 \mathrm{~g})$ is high when compared to $36.31 \mathrm{mg} / 100 \mathrm{~g}$ of Annona muricata and $62.79 \mathrm{mg} / 100 \mathrm{~g}$ of Vernonia amygdalina [15-16]. Calcium content of Celosia argentea $(295 \mathrm{mg} / 100 \mathrm{~g})$ is low when compared to $1118.30 \mathrm{mg} / 100 \mathrm{~g}$ of Annona muricata and $1264.18 \mathrm{mg} / 100 \mathrm{~g}$ of Vernonia amygdalina [15-16]. Calcium is known to play a significant role in muscle contraction, bone and teeth formation and blood clotting [25-26]. Sodium and potassium which are present in the intracellular and extracellular fluid helps to maintain electrolyte balance and membrane fluidity. It is known that inorganic mineral elements such as potassium, calcium play important roles in the maintenance of normal glucose-tolerance and in the release of insulin from beta cells of islets of Langerhans [27].

Magnesium content of Celosia argentea $(122.53 \mathrm{mg} / 100 \mathrm{~g})$ is low when compared to $961.9 \mathrm{mg} / 100 \mathrm{~g}$ of Annona muricata and $681.36 \mathrm{mg} / 100 \mathrm{~g}$ of Vernonia amygdalina [15-16]. Magnesium is a composition of chlorophyll and it is an important content in connection with Ischemic heart disease and calcium metabolism in bones [28](Ishida et al., 2000). Some of these minerals such as magnesium are needed as cofactor in enzyme catalysis in the body [25].

Zinc content of Celosia argentea $(5.42 \mathrm{mg} / 100 \mathrm{~g})$ is high when compared to $0.83 \mathrm{mg} / 100 \mathrm{~g}$ of Annona muricata and $1.42 \mathrm{mg} / 100 \mathrm{~g}$ of Vernonia amygdalina [15-16]. Zinc is involved in normal functioning of immune system [29] and is associated with protein metabolism. The leaves are a good source of zinc because it is far above 6.23 recommended by RDA [30].

Iron content of Celosia argentea $(35.16 \mathrm{mg} / 100 \mathrm{mg})$ compared favourably with $32.20 \mathrm{mg} / 100 \mathrm{~g}$ of Vernonia amygdalina but high when compared to $13.95 \mathrm{mg} / 100 \mathrm{~g}$ of Annona muricata as reported by Usunobun and Okolie [15-16]. This perhaps justifies the already locally established function of the plant in the regulation of haemoglobin level. Iron is an essential trace element for hemoglobin formation, normal functioning of central nervous system and in the oxidation of carbohydrates, protein and fats [31]. Iron is known to be a component of some metalloenzymes, myoglobin and heamoglobin [25], which is needed in the transport of oxygen and carbon dioxide during respiration or cellular metabolism. This heamoglobin (containing iron) also serve as buffer to regulate changes in blood $\mathrm{pH}$ [32].

With regard to reducing power activity and DPPH radical scavenging activity, Celosia argentea leaves showed a concentration dependent activity and comparing its DPPH-radical scavenging activity and that of the standard (Vitamin C), it can be stated that Celosia argentea leaves would offer protection against oxidative damage to body cells. The concentration-dependent increase in reducing power ability and DPPH radical scavenging reflects the very high antioxidant activity of Celosia argentea and may justify its use as an antidote by some locals.

In conclusion, Celosia argentea leaves should continue to be used as food since it contains valuable phytochemicals and minerals. The traditional medicinal use should also continue since it contains many valuable phytochemicals (alkaloids, flavonoids etc) which are the basis for plant medicinal starting materials, in the synthesis of new drugs.

\section{References}

[1] Grubben GJH. \& Denton OA. (2004). Plant Resources of Tropical Africa 2 (Vegetables). PROTA Foundation, Wageningen, Netherlands. Pp. $167-173$.

[2] Tindall HD. (1983). Vegetables inthe Tropics. Macmillan Press Limited, London. Pp. 37 -45.http://dx.doi.org/10.1007/978-1-34917223-8.
[3] Budin, JT., Breene,WM. \& Putnam DH. (1996). Some Compositional Properties of Seeds and Oils of eight Amaranthus Species. Journal American Oil Chemical Society73, 475 481.http://dx.doi.org/10.1007/BF02523922.

[4] Chweya, JA. \& Eyzaguirre PB. (1999). the Biodiversity of Traditional Leafy Vegetables. International Plant Genetic Resources Institute. Rome pp. $15-45$.

[5] Burkill, HM. (1995). Useful Plants of West Tropical Africa. Royal Botanic Gardens Press, Kenton UK

[6] Santosh SB, Sohan SC, Anupamaa S, Devanand BS, \&Manohar JP. (2008). Anti- inflammatory activity of an isolated flavonoid fraction from Celosia argentea Linn. Journal of Medicinal Plants Research 2(3), 52-54.

[7] Wiart C. (2000). Medicinal Plants of Southeast Asia. Malaysia: Pelanduk Publications (M) Sdn. Phd.

[8] Duke JA, \& Ayensu ES. (1985). Medicinal Plants of China, Vol. 1 \& 2. United States of America: Reference Publication, Inc.

[9] Jain SK \& Defilipps RA. (1991). Medicinal Plants of India, Vol. 1 and 2. United States of America: Reference Publication, Inc.

[10] Sofowora LA. (1993). Medicinal plants and Traditional Medicine in Africa. Spectrum Books Ltd, Ibadan, pp55-71.

[11] Trease GE \& Evans WC. (1985). Pharmacognosy 11th Ed., Tindall Ltd, London, pp60-75.

[12] Harbone, JB. (1998). Methods of extraction and isolation. In: Phytochemical Methods. Chapman and Hall, London;Pp60-66.

[13] Usunobun U, Okolie NP, Anyanwu OG.Adegbegi AJJ \& Egharevba ME. (2015).Phytochemical screening and proximate composition of Annona muricata leaves. European Journal ofBotany, Plant science and Phytology 2(1), 18-28.

[14] Usunobun U \& Okolie PN (2016). Phytochemical analysis and proximate composition of Vernonia amygdalina. International Journal of Scientific World 4 (1), 1114http://dx.doi.org/10.14419/ijsw.v4i1.5845.

[15] Usunobun U \& Okolie NP (2015). Phytochemical analysis and mineral composition of Annona muricata leaves. International Journal of Research and Current Development 1(1), 38-42.

[16] Usunobun U \& Okolie NP. (2015). Phytochemical, trace and mineral composition of Vernonia amygdalina leaves. International Journal of Biological and Pharmaceutical Research. 6(5), 393-399.

[17] Tsuchiya H. (2010). Structure-dependent membrane interaction of flavonoids associated with their bioactivity. Food Chemistry 1201089-1096

[18] Cook NC \& Samman S. (1996). Flavonoids: Chemistry, metabolism, cardioprotective effects and dietary sources. Nutritional Biochemistry 7, 66-76.http://dx.doi.org/10.1016/0955-2863(95)001689.

[19] Schnier M, Sies H, Illek B, \& Fischer H (2005). Cocoa-related flavonoids inhibit CFTR- mediated chloride transport acrossT84 human colon epithelia. Journal of Nutrition 135(10), 2320-5.

[20] Galeotti F, Barile E, Curir P, Dolci M, \& Lanzotti V (2008). "Flavonoids from carnation (Dianthus caryophyllus) and their antifungal activity". Phytochemistry Letters. 1, 44.http://dx.doi.org/10.1016/j.phytol.2007.10.001.

[21] Cushnie TP, \& Lamb AJ (2005). Antimicrobial activity of Flavonoids. International Journal of Antimicrobial Agents 26 (5), 343356.http://dx.doi.org/10.1016/j.ijantimicag.2005.09.002.

[22] Lewis WH \& Elvin-Lewis MP (1995). Medicinal plants as sources of new therapeutics. Ann. Mo. Bot. Gard. 82,1624http://dx.doi.org/10.2307/2399976.

[23] Forester J \& Hartmut T (2006). "MetaCyc Pathway: saponin biosynthesis I". Advances in Experimental Medicine and Biology, 405, 377- 385.

[24] Onwordi CT, Anuoluwa MO \& DW Adedoja (2009). The proximate and mineral composition of three leafy vegetables commonly consumed in Lagos, Nigeria. African Journal of Pure and Applied Chemistry3(6), 102-107.

[25] Ahmed D, \& Chaudhary MA (2009) Medicinal and nutritional aspects of various trace metals determined in Ajugabracteosa. Journal Applied Science and Research 5(7), 864-869.

[26] Heaney RP (2009) Dairy and bone health. Journal of American Coll Nutrition 28(1), 82S-90S. http:// dx.Doi .org/ 10.1080/ 07315724. 2009.10719808 .

[27] Choudhary KA \& Bandyopadhyay NG (1999) Preliminary studies on the inorganic constituents of some indigenous hyperglycaemic herbs on oral glucose tolerance test. Journal of Ethnopharmacology 64, 179- 184.http://dx.doi.org/10.1016/S0378-8741(98)00118-4.

[28] Ishida H, Suzuno H Sugiyama N, Innami S \& Todokoro, T. (2000). National evaluation of chemical component of leaves stalks and stem of sweet potatoes (Ipomea batata) poir. Food Chemistry. 68, 359- 367.http://dx.doi.org/10.1016/S0308-8146(99)00206-X. 
[29] Ibrahim NDG, Abdurahman EM, \& Ibrahim G,(2001). "Elemental analysis of the leaves of Vernonia amygdalina and its biological evaluation rats," Nigeria Journal of Natural Products and Medicine 5, 13-16.http://dx.doi.org/10.4314/njnpm.v5i1.11715.

[30] Borgert GM \& Calloway H, (1975). Nutritional and physical fitness, W. B saunder and Co., Philadephia, USA, pp. 34-50.

[31] Adeyeye E, \&Otokiti MKO (1999) proximate composition and some nutritional valuable minerals of two varieties of Capsicum annum (bell and cherry peppers). Discovery and Innovations 11, 75 -81 .

[32] Kamshilov IM \& Zaprudnova RA (2009) Interspecies differences of hemoglobin buffer properties and of ion environment in some freshwater fish. Journal of Evolutionary Biochemistry and Physiology45(2), 242-244.http://dx.doi.org/10.1134/S0022093009020121. 